\title{
Physicians ready for home truths: CMA past president
}

$\mathrm{P}$ hysicians are ready to be held to a higher standard of accountability, says Dr. Louis Hugo Francescutti, past president of the Canadian Medical Association (CMA). In his parting address at CMA General Council in Ottawa Aug. 20, he issued a scathing review of the profession, urging doctors to "step up and quit pointing blame" for Canada's failing health system.

Physicians have squandered their "monopoly" over medicine, said Francescutti, citing poor international performance, declining patient satisfaction and rising medico-legal settlements.

The fix: radical accountability, best modelled by Ohio's Cleveland Clinic. The celebrated clinic hires physicians on one-year contracts and conducts annual performance reviews.

Francescutti joined CMAJ by phone to discuss reaction to his remarks as well as his hope for a more accountable profession.

CMAJ: You must have known your valedictory address would make waves at General Council; how did your peers respond to your remarks?

Francescutti: I thought there'd be more of a defensive reaction but there wasn't. The only concern was that the systems people are working in aren't sophisticated enough to provide the feedback they need to improve their performance ... which suggests that physicians are prepared to be held to greater accountability if they feel the evaluation is meaningful.

\section{CMAJ: How did CMA respond?}

Francescutti: I'm going to [Ohio] with the current and incoming presidents, and the CEO of the Royal College of Physicians and Surgeons, to find out exactly why the Cleveland Clinic has had such success. ... I think [employing physicians on annual contracts] makes them exceptional, because they have to perform at the highest level.

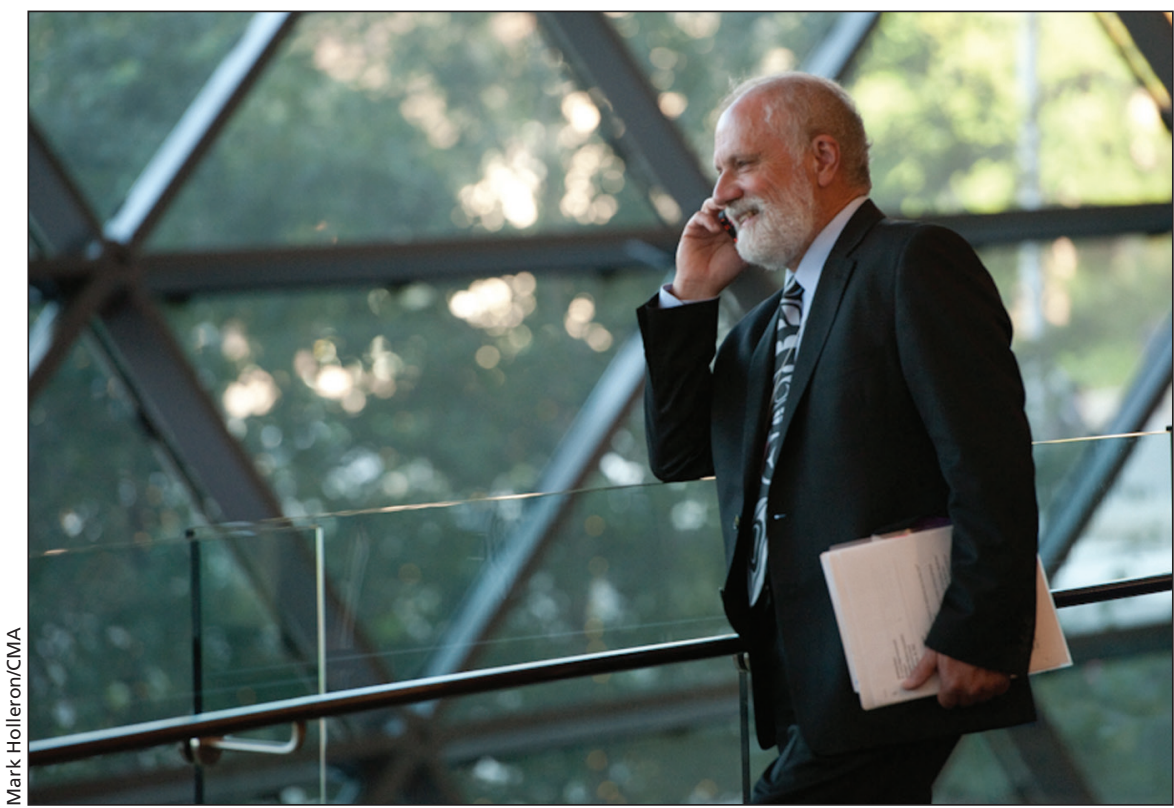

Doctors need tough love and high expectations, says CMA Past President Dr. Louis Hugo Francescutti, defending his controversial parting speech.

CMAJ: In your speech, you said that Canada's current system may not be capable of the "meaningful accountability" modelled at the Cleveland Clinic. Is there another model that might work here and now?

Francescutti: The most important model is self-accountability. Every month ask yourself, have you been compassionate and available to your patients? Have you delivered highquality service? I try to do it on a shiftby-shift basis.

CMAJ: What is it about the current system that makes it so difficult for physicians to live up to that ideal?

Francescutti: You don't get the feedback on your performance immediately; you get it indirectly, years down the road, through [agencies like the Canadian Institute for Health Information]. In professional hockey, players know at the end of the game how long they had the puck, how many shots they took, what errors they made.

CMAJ: How do you respond to physicians who are working at their limits and feel these are system problems outside their control?

Francescutti: If these are system problems, you've got to get involved in the system. Everyone wants to do doctor stuff — pharmacists, nurses but when a critically ill patient shows up, everyone else is gone. If you look at the health system as that patient, physicians are the ones that have to step up.

CMAJ: Is it fair to task physicians with triaging the health system? Isn't that what's been happening for years - offloading administration onto doctors?

Francescutti: Nobody else is stepping up and showing the leadership required. ... We are the people in the room and we have to convince ourselves and our colleagues that it's imperative we do better, and that we have limited time.

CMAJ: Were you preaching to the choir at general council?

Francescutti: That could be true. The other side is, if they are supposed 
to be physician leaders, why do we still have such major problems? ... Are they pushing the envelope as far as it could go? I don't think they are.

CMAJ: Why does it take so long for the profession to have these discussions, particularly about accountability?

Francescutti: Humans aren't designed to have crucial conversations ... the natural reaction is freezing, fighting or running away. ... But if you don't have crucial conversations, you're not going to have accountability.

CMAJ: What might make physicians more comfortable with having a critical eye turned on their work?

Francescutti: Anyone drawing dollars from the public purse should be comfortable that people are watching what they do - that's part of the territory. We just want a level process. ... [Ideally] everyone else in the system will be held to the same standard.

CMAJ: Why is the profession at this crossroads now?

Francescutti: We've been riding the coattails of the men and women that came before us. We've been using their currency and depleted it, and you see that in how our ratings are dropping quite considerably in the past 10 years.

CMAJ: What were they doing differently before?

Francescutti: They weren't as strained. They were well-financed. There were no regional health authorities. Everyone worked in individual institutions and they had pride in their institutions. ... We've lost that and then we've had a generational shift as well.

CMAJ: Why is that important?

Francescutti: We have four generations practising right now and you're not going to find a solution for each of those generations with one message. You have to tailor the message to each of the different generations.

CMAJ: How can CMA move this issue forward?

Francescutti: That's why we're going to the Cleveland Clinic. We hope to tie [lessons from the clinic] into our health care transformation agenda and show how physicians can be big players in the new way of doing things. - Lauren Vogel, CMAJ

CMAJ 2014. DOI:10.1503/cmaj.109-4896 